\title{
PESTICIDE RESIDUES EVALUATION IN BRAZILIAN BASIC DIET: RICE AND BEAN
}

\author{
CLAUDIA HELENA PASTOR CISCATO * \\ GISELE SANTOS SOUZA ** \\ CLÁUDIA MARIA BARBOSA *** \\ AMIR BERTONI GEBARA ****
}

\begin{abstract}
Rice and bean constitute the basic diet in underdeveloped countries. In Brazil, the acquisition per capita of these aliments is around $182.9 \mathrm{~g} /$ day (beans) and $160.3 \mathrm{~g} /$ day (rice). In the present work were evaluated the pesticide residue contamination on these aliments, and possible risks for the consumer health. Pesticide residues were evaluated in 364 bean samples and 143 rice samples commercialized in Sao Paulo City (BRAZIL). A multi-residue method (DFG S19) was employed with gas and liquid chromatography identification and quantification. Dietary intake estimation was processed using the Acute Dietary Ingestion (ADI) based on national data regarding food consumption. Residues of pesticides that, according to the Brazilian legislation, are not allowed for this culture were detected respectively in $4.5 \%$ and $3.6 \%$ of the bean and rice samples. However, none of the samples had pesticide residues above the Maximum Residue Level (MRL). The European Union (EU) database showed that 7.3\% of the bean sample and $85.7 \%$ of rice presented pesticide residues above the MRL. The toxicological parameter used for assessing the risk of contamination (ADI <100\%) was not exceeded in none of the commodities. The results do not pose a hazard for the consumer's health. Nevertheless, the presence of multiple residues indicates that continuous studies and monitoring of these commodities are required.
\end{abstract}

* PhD, Biological Science, Pesticide Residues Laboratory (LRP), Instituto Biológico (IB), São Paulo, SP, Brasil (e-mail: ciscato@biologico.sp.gov.br).

** Chemist, LRP, IB, São Paulo, SP, Brasil (e-mail:gisa_vedder@hotmail.com).

*** Biologist, LRP, IB, São Paulo, SP, Brasil, (e-mail: claudiamariabarbosa@yahoo.com.br).

**** PhD, Public Health, LRP, IB, São Paulo, SP, Brasil (e-mail: Gebara@biologico.sp.gov.br). 


\section{INTRODUCTION}

The basic diet in underdeveloped and developing countries consists of rice and beans, which supply a great source of fiber and nutrients. In Brazil, according to IBGE (Instituto Brasileiro de Geografia e Estatística - Geographic and Statistic Brazilian Institute), the per capita acquisition is $5.8 \mathrm{~kg}$ of rice and $6.7 \mathrm{~kg}$ of bean per year (IBGE, 2011). These commodities participate with almost $50 \%$ of the total human basic necessity of calories (LEVY-COSTA et al., 2005). The Food and Agricultural Organization (FAO) ranking poses Brazil as the $10^{\text {th }}$ rice-producing country and the $1^{\text {st }}$ bean-producing country (FAO, 2007).

According to Brazilian Livestock and Agricultural Ministry (MAPA - Ministério da Agricultura, Pecuária e Abastecimento), Japan and countries from Africa, Europe, and America are frequent consumers of rice and beans (MAPA, 2010). Brazil produces around 13.5 thousand tons of rice and 3.5 thousand tons of beans and the South and Southeast are the main production regions. Nevertheless, the loss affected by pests reaches almost $60 \%$. Pesticides are normally used in these agricultural cultures production. Rice can be considered an important commodity in the pesticide market, since it consumes almost $2 \%$ of the total commercialized.

The national legislation (ANVISA, 2011), allege that there are 105 pesticide registries for bean and 78 for rice, being some active substances common for both commodities (39 pesticides). The International parameters of MRL from Codex Alimentarius and European Union (EU) are quite different; such information is important to understand the differences between national and international data.

According to Garcia, Bussacos \& Fisher (2005), the Brazilian legislation for pesticide use and control has begun more formalized in the eighties (Brazilian Pesticide Law, $n^{\circ} 7802 / 89$ ). The government agencies involved in such work have defined the necessity of agricultural and environmental practices to public health maintenance. Brazil and other Latin America countries (Argentina, Chile, Costa Rica and Ecuador) have been participating in the International Atomic Energy Agency (IAEA) Coordinated Research Project (CRP), which investigates a more holistic approach to food and environmental safety (LOEWY et al., 2009). The main subject of this commission is to adopt the same position about the good agricultural practices (GAP) and good laboratory practices (GLP), as the necessity to register a new molecule or to re-evaluate a pesticide molecule, which is already being practiced in developed countries.

Monitoring studies are a good strategy to evaluated food quality control. The present work aimed to evaluate the presence of pesticide residues in samples of bean and rice commercialized in São Paulo city (BRAZIL) and verify the compliance with maximum residue levels (MRL) established by national and international agencies, as well as possible risks for health.

\section{MATERIAL AND METHODS}

This study was developed from January 2006 to December 2007 and were evaluated 143 rice (polished) samples and 364 bean (dry) samples commercialized in Sao Paulo City. The samples were analyzed immediately, employing the multiresidue method DFG S19 (2009). Almost 140 active ingredients were studied, including organochlorines, organophosphorus, pyrethroids, carbamates and others insecticides, some fungicides and herbicides.

In brief, the samples were triturated, homogenized and an aliquot was extracted with acetone. Partition step was processed with a mixture of cyclohexane + ethyl acetate (1:1). The cleanup was performed by gel permeation chromatography (GPC) with Bio Beads ${ }^{\circ} \mathrm{S}-\mathrm{X} 3$ polystyrene gel and an additional clean-up step with silica gel deactivated $1.5 \%$ was employed for analysis by electron capture detector.

Identification and quantification of pesticides were carried out by gas chromatography (GC) with electron capture detector (ECD), nitrogen/phosphorus detector (NPD), flame photometric detector (FPD) and high pressure liquid chromatography (HPLC) with UV/Vis and fluorescence detectors. All confirmations were carried out by liquid chromatography with mass spectrometer (LC/MS/MS). 
Validation of the multi-residue method employed at Laboratorio de Residuos de Pesticidas (LRP), was undertaken with the criteria for analytical performance established by International Union of Pure Applied Chemistry (IUPAC) Technical Report (THOMPSON, ELLISO \& WOOS, 2002). Due to the differing characteristics of pesticides and matrixes, in order to establish the working range for pesticide/matrix combination, the products were placed in groups, taking into account the mode of pesticide action and matrixes water percentage.

The working ranges were: 0.002 to $0.01 \mathrm{mg}^{\mathrm{kg}} \mathrm{g}^{-1}$ for organochlorine insecticides, 0.01 to $0.1 \mathrm{mg} \cdot \mathrm{kg}^{-1}$ for organophosphorus insecticides and pyrethroids insecticides, 0.05 to $0.1 \mathrm{mg} \cdot \mathrm{kg}^{-1}$

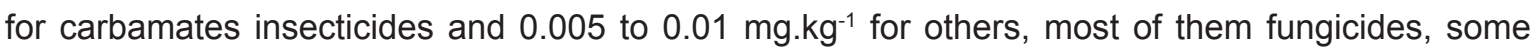
herbicides, nematicides and acaricides. Recoveries ranged from 70 to $120 \%$. Positive results were confirmed by using different techniques including LC/MS/MS. The concentrations were calculated by using a calibration curve generated from peak area.

The LRP has been annually participating in proficiency testing schemes with satisfactory performance.

The dietary intake for positive samples was calculated using the general equation:

Intake ${ }^{*}=$ Concentration of pesticide in food eaten $\left(\mathrm{mg} \cdot \mathrm{kg}^{-1}\right) \times$ Food quantity eaten $(\mathrm{kg})$

$$
\text { Body weight of an adult }(60 \mathrm{~kg})
$$

* (mg of pesticide/kg body weight)

\section{RESULTS AND DISCUSSION}

In the present study, according to the Brazilian legislation, $77.8 \%$ of bean samples and $96.4 \%$ of rice samples were not contaminated by pesticide residues. Among the positive samples, $4.5 \%$ of bean and $3.6 \%$ of rice contained residues of pesticides that are not allowed for these crops. None of the samples had pesticide residues above the Maximum Residue Level (MRL). Tables 1 and 2 show the pesticides, their concentration levels and the national and international MRL.

Since rice and beans are important food items, composing people's diet in many countries, the compliance with the international legislation must be verified. According to the Codex Alimentarius (CODEX, 2012), only 2 pesticides found in the samples have a MRL. Although Codex MRL corresponded to data addressed by the industries, they are recognized by the World Trade Organization (WTO) for food safety issues which affect international trade and are used as the basis of any trade disputes.

\section{TABLE 1 - PESTICIDE RESIDUES BY CONCENTRATION LEVELS DETECTED IN THE BEAN SAMPLES AND THE MRL, 2006-2007}

\begin{tabular}{|c|c|c|c|c|c|c|c|}
\hline \multirow[t]{2}{*}{ Pesticide } & \multicolumn{4}{|c|}{ Residues mg.kg-1 } & \multicolumn{3}{|c|}{ MRL } \\
\hline & $\leq 0.01$ & $\leq 0.05$ & $\leq 0.1$ & $>0.1$ & Brazil & Codex & EC \\
\hline chlorpyriphos & 4 & 0 & 0 & 0 & 0.1 & - & 0.05 \\
\hline chlorothalonil & 5 & 4 & 0 & 0 & 0.1 & 0.2 & 0.01 \\
\hline cyhalothrin lambda & 1 & 0 & 0 & 0 & 0.05 & - & 0.2 \\
\hline diazinon & 0 & 0 & 2 & 2 & NPC & - & 0.01 \\
\hline endosulfan & 11 & 2 & 0 & 0 & NPC & - & 0.05 \\
\hline $\mathrm{HCH}$ alpha & 2 & 0 & 0 & 0 & NPC & - & 0.01 \\
\hline iprodione & 1 & 0 & 0 & 0 & 0.5 & 0.1 & 0.02 \\
\hline procymidone & 26 & 23 & 13 & 14 & 0.5 & - & 1.0 \\
\hline
\end{tabular}

NPC - not permitted for the crop; Ec = European Comission. 
TABLE 2 - PESTICIDE RESIDUES BY CONCENTRATION LEVELS DETECTED IN RICE SAMPLES AND THE MRL, 2006-2007

\begin{tabular}{cccccccc}
\hline \multirow{2}{*}{ Pesticide } & \multicolumn{4}{c}{ Residues mg.kg-1 } & \multicolumn{3}{c}{ MRL } \\
\cline { 2 - 8 } & $\mathbf{5 0 . 0 1}$ & $\mathbf{5 0 . 0 5}$ & $\mathbf{5 0 . 1}$ & $>\mathbf{0 . 1}$ & Brazil & Codex & EC \\
\hline chlorothalonil & 0 & 1 & 0 & 0 & NPC & - & 0.01 \\
diazinon & 0 & 2 & 0 & 1 & NPC & - & 0.02 \\
procymidone & 0 & 1 & 0 & 1 & 3.0 & - & 0.02 \\
tetradifon & 0 & 0 & 1 & 0 & NPC & - & 0.02 \\
& & & & & & & \\
\hline
\end{tabular}

NPC - not permitted for the crop; Ec = European Comission.

The European Commission (EC) databases have the MRL for all pesticides detected in this study. It is important for its members that the EC applies the quantification limit concept to establish the MRL of pesticide residues which are not currently used (EUROPEAN COMMISSION, 2012). The positive samples in comparison with this legislation demonstrated that $7.3 \%$ and $85.7 \%$ (bean and rice respectively) of all positive results corresponded to pesticide residues above the MRL, Tables 1 and 2. Multiple residues were found in one sample of rice and 21 samples of bean, Table 3 . The fungicide procymidone was the most frequently found compound.

TABLE 3 - MULTIPLE PESTICIDE RESIDUES IN BEAN AND RICE SAMPLES, 2006-2007

\begin{tabular}{cl}
\hline Commodity & Multiple residues \\
\hline Bean & 5 samples - chlorothalonil+procymidone \\
& 1 sample - chlorothalonil+endosulfan \\
& 1 sample - chlorothalonil+cyhalothrin lambda \\
& 1 sample - chlorpyriphos+procymidone \\
& 1 sample - diazinon+procymidone \\
& 9 samples - endosulfan+procymidone \\
& 1 sample - HCH alpha+procymidone \\
& 1 sample - chlorothalonil+chlorpyriphos+procymidone \\
& 1 sample - diazinon+endosulfan+procymidone \\
& 1 sample - chlorothalonil+procymidone+tetradifon \\
\hline
\end{tabular}

Toxicological evaluation (ADI\% $\leq 100)$ demonstrated that the parameter was not exceeded for both commodities. Multiple findings of pesticide residues should be considered carefully, especially the cocktail effect in acute toxicity for some classes of pesticides. The values were at maximum $25 \%$ of ADI using the IBGE (2011) Brazilian diet and GEMS/FOOD (2003) diet for Latin America.

Comparing the results of this study with the data from the monitoring program at EU during the period from 2000 to 2005 (EFSA, 2010), the negative samples of bean and rice are quite the same (medium of $63.5 \%$ for bean and $86 \%$ for rice), and the pesticides, diazinon, lambda-cyhalothrin, endosulfan, chlorothalonil, chlorpyrifos and procymidone were also detected. The same panorama was noticed by Bobbis et al. (2008), the authors emphasized that even the values above the MRL for the EU, they did not exceeded the ADI parameter, suggesting that the food quality for the consumers could be considered safe for consumption relating to pesticide residues contamination.

In Brazil, the National Pesticide Monitoring Program (PARA) showed that $4.4 \%$ of bean 
samples and $2.9 \%$ of rice samples were contaminated by pesticide residues not allowed for the crop and above the MRL (ANVISA, 2011).

Caldas \& Souza (2000) and Enes and Silva (2005) observed that some products registered in Brazil have the ADI surpassed and such results could be attributed to regional diets. The authors suggest that bean and rice are the main food items in such scene.

Pesticide residues evaluated in others commodities during the same period, presented pesticide residues above the MRL. Ciscato, Gebara \& Monteiro (2009), observed in fruit samples that $76.8 \%$ were not contaminated by pesticide residues and $5.4 \%$ presented residues above the MRL. Multiple residues were observed in the samples and the pesticides found were: carbendazim, cypermethrin, chlorothalonil, chlorpyrifos, deltamethrin, dithiocarbamates, endosulfan, parathion methyl, procymidone, tetradifon and thiabendazole.

\section{CONCLUSION}

Concerning safe consumption of the samples analyzed in this study, it is plausible to consider that the compounds found in the samples, even those above the MRL by the international legislation, do not pose a hazard for consumer's health. Nevertheless, the presence of multiple findings as well as not allowed pesticides for such crops suggest the necessity of continuous monitoring studies, which will contribute to maintain food quality control. The evaluation of pesticide residues is an important way to minimize the risk of health exposure to contaminants and to guarantee the environmental protection.

\section{RESUMO}

\section{AVALIAÇÃo DE RESÍDUOS DE AGROTÓXICOS NA DIETA ALIMENTAR BRASILEIRA: ARROZ E FEIJÃO}

O arroz e o feijão constituem a dieta básica em países do terceiro mundo. No Brasil, a aquisição per capita desses alimentos é de 182,9 g/dia de feijão e 160,3 g/dia de arroz. Neste trabalho foi avaliada a contaminação desses alimentos por resíduos de pesticidas e a possibilidade de risco à saúde dos consumidores. Foram avaliadas 364 amostras de feijão e 143 amostras de arroz comercializadas na cidade de São Paulo (BRASIL). Utilizou-se o método multirresíduos com identificação e quantificação por cromatografia a gás e a líquido. Calculou-se a estimativa da ingestão diária aceitável (IDA) a partir dos dados de consumo pela população brasileira. Resíduos de agrotóxicos não permitidos para a cultura de acordo com a legislação brasileira foram encontrados em respectivamente, $4,5 \%$ e 3,6\% das amostras de feijão e arroz, sendo que nenhuma amostra ultrapassou o limite máximo de resíduos (LMR). Dados da União Europeia (EU) demonstraram que $7.3 \%$ e $85.7 \%$ das amostras de feijão e arroz, respectivamente, apresentaram níveis de resíduos acima do LMR. A avaliação toxicológica demonstrou que a IDA não foi ultrapassada em nenhuma das amostras analisadas. Os resultados não sugerem risco à saúde dos consumidores, porém a presença de resíduos múltiplos indica a necessidade de estudos contínuos de monitoramento desses alimentos.

PALAVRAS - CHAVE: RESÍDUOS DE PESTICIDAS; IDA; FEIJÃO; ARROZ; MULTIRRESÍDUOS.

\section{REFERENCES}

1 ANVISA. Agência Nacional de Vigilância Sanitária. Programa de análise de resíduos de agrotóxicos em alimentos (PARA). Available at: <http://www.anvisa.gov.br/toxicologia/residuos/index.htm>. Access on: Jun. 13 ${ }^{\text {th }}, 2011$.

2 ANVISA. Agência Nacional de Vigilância Sanitária. Monografias - agrotóxicos. Available at: <http://portal.anvisa.gov.br/

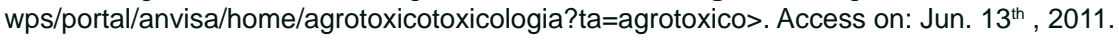

3 BOOBIS, A.R.; OSSENDORP, B.C.; BANANSIAK, U.; HAMEY, P.Y.; SEBESTYEN, I.; MORETTO, A. Cumulative risk assessment of pesticide residues in food. Toxicology Letters, v.100, p. 137-150, 2008.

4 BRASIL. Ministério da Agricultura, Pecuária e Abastecimento. Estatisticas: produção de grãos. Available at: <HTTP:// www.agricultura .gov.br/ vegetal /estatísticas>. Access on: Fev. 15 2012.

5 CALDAS, E.D.; SOUZA, L.C.K.R. Avaliação de risco crônico da ingestão de resíduos de pesticidas na dieta brasileira. 
Journal of Public Health, v. 34, n. 5, p. 529-37, 2000.

6 CISCATO, C.H.P.; GEBARA, A.B.; MONTEIRO, S.H. Pesticide residue monitoring of Brazilian fruit for export $2006-2007$. Food Additives and Contaminants: Part b, v. 2, n. 2, p. 140-145, 2009.

7 CODEX ALIMENTARIUS. Pesticide residues in food and feed. Codex Pesticides Residues in Food on line Database. Available at: <http://www.codexalimentarius.net/pestres/data/index.html>. Access on: Aug. $18^{\text {th }}, 2012$.

8 DFG. Deutsche Forschungsgemeinschaft. Modular multiple revised version of the DFG method S19. Modular multiple analytical method for the determination of pesticide residues in foodstuffs. Collection of Official Methods under article 35 of the German Federal Food Act as method L00.00-34 (1999). Available at: http://www.methodensammlungbvl.de/cn/bGV2ZWw9dHBsLXN1Y2hlcmdlYm5pcyZsaW1pdGF0aW9udH1wZT0mc2VhcmNoYWNjZXNza2V5PUNPT1 RTF1QmcGFnZW1kPTY*html Access on: Oct. 10"th 2009.

9 EFSA. European Food Safety Authority. Annual Report on Pesticide Residues according to article 32 of Regulation (EC) n 396/2005. EFSA Journal, v. 8, n. 7, p. 1646, 2010 Available at: <http://www.efsa.europa. eu/en/ efsajournal/ pub/1646. htm>. Access on: Jun. 14 ${ }^{\text {th }}, 2011$.

10 ENES, C.C.; Silva, M.V. O potencial de ingestão de resíduos de pesticidas por meio da alimentação disponível nos domicílios das famílias da região sul do Brasil. Revista de Higiene Alimentar, v.19, n. 136, p. 36-40, 2005.

11 EUROPEAN COMMISSION. Health and consumers - food safety - from the farm to the fork. Available at: http:// ec.europa.eu/food/index_en.htm Access on: Aug 18 ${ }^{\text {th }}, 2012$.

12 FAOSTAT. Food and agricultural commodities production. Available at: <http://faostat.fao.org/site/339/default.aspx>. Access on: Feb. 15 $5^{\text {th }}, 2012$.

13 GARCIA, E. G.; BUSSACOS, M. A.; FISHER, F. M. Impacto da legislação no registro de agrotóxicos de maior toxicidade no Brasil. Rev. Saúde Pública, v. 39, n. 5, p. 832-9. 2005

14 GEMS/FOOD. Global Environment Monitoring System. Guidelines for predicting dietary intake of pesticide residues (revised). Prepared by the Global Environment Monitoring System - Food Contamination Monitoring and Assessment Program. Available at: < www.who.int/foodsafety/publications/chem/en/pesticide_en.pdf > Access on: Aug. $18^{\text {th }}, 2012$.

15 GEMS/FOOD. Global Environment Monitoring System. Regional per capita consumption of raw and semi processed agricultural commodities. 2003. Available at: <http://www.foodrisk.umd.edu/resource_types/databases/commodities. cfm?keyword=General>. Access on: Jan. $20^{\text {th }} 2011$.

16 IBGE. Instituto Brasileiro de Geografia e Estatística. Pesquisa de orçamentos familiares 2008-2009: análise do consumo alimentar pessoal no Brasil, RJ. Available at: <HTTP://www.ibge.gov.br/home/estatistica/ populaao/ condicaodevida/ pdf/2008-2009_analise-consumo/defaultlab_pdf_energia .shtm>. Access on: Jan. 20 2011.

17 LEVY-COSTA, R.B.; SICHIERI, R.; PONTES, N.S.; MONTEIRO, C.A. Disponibilidade domiciliar de alimentos no Brasil: distribuição e evolução (1974-2003). Journal of Public Health, v. 39, n. 4, p. 530-440, 2005.

18 LOEWY, R.M.; SAVINI, M.; MONZA, L.; KIRS, V.; LUCHINI, L.; BAGGIO, D.; GONZAGA, F.; NARIO, A.; PINO, I.; PARADA, A.M.; VIDELA, X.; CASTRO, R.; PASTOR, Y.; CHICA, I.; CARAZO, E.; CHINCHILLA, C.; MATARRITA, J.; MAESTRONI, B.; FERRIS, I. Assessing good agricultural practice: comparative pesticide impact. In: LATIN AMERICAN PESTICIDE RESIDUE WORKSHOP, 2., Santa Fé. Annals ... Santa Fé: Universidad Nacional del Litoral, 2009. p. 229.

19 THOMPSON, M.; ELLISON, S.L.R.; WOOS, R. Harmonized guidelines for single-laboratory validation of methods of analysis (IUPAC Technical Report, 1999). Pure Applied Chemistry, v. 74, n. 5, p. 835-855, 2002. 